\title{
Editorial
}

Neonatology

\section{Cochrane Review Update}

In this issue of Neonatology, we introduce a new section entitled Cochrane Review Updates prepared under the guidance of Dr. Roger Soll from Burlington, Vermont, who is currently the Director of the Neonatal Review Group of the Cochrane Collaboration. We are very grateful to Dr. Soll for taking the time to write commentaries on the extended abstracts of updated neonatal systematic reviews and agreeing to have them published in Neonatology. This initiative arises from our previous Editorial Notes calling for submission to the journal of more randomized controlled trials and systematic reviews $[1,2]$. The response from our readers has been very impressive as can be judged by the articles listed in April's top 10 on the journal website [http://www.karger.com/NEO_Top10_Articles] where 6 are systematic reviews and meta-analyses [3-8]. The list of topics is interesting and varied including surfactant therapy for meconium aspiration syndrome, postnatal steroids for bronchopulmonary dysplasia, volume-targeted versus pressure-limited ventilation, optimal oxygen saturations for very preterm infants and oral ibuprofen versus intravenous ibuprofen or intravenous indomethacin for patent ductus arteriosus. These are all areas where doubts remain about the best clinical management of preterm infants in neonatal intensive care units.

In this issue of Neonatology, Dr. Soll begins with the updated Cochrane review entitled 'Early erythropoietin for preventing red blood cell transfusion in preterm and/ or low birth weight infants' [9]. This is an important update for readers of Neonatology and we hope you enjoy reading it along with Dr. Soll's commentary which puts the findings into context. In later issues of the journal, we will publish Cochrane Review Updates on prophylactic surfactant, high-frequency oscillatory ventilation and inhaled nitric oxide to prevent bronchopulmonary dyspla- sia in very preterm infants. After these we hope that further updates will appear at regular intervals to keep you up to date with developments in neonatal Cochrane systematic reviews. Readers, we would welcome your feedback on this new initiative with further suggestions of how we might continue to improve Neonatology and its relevance to clinical practice.

Henry L. Halliday, Belfast Christian P. Speer, Würzburg

\section{References}

1 Halliday HL, Speer CP: Editorial note: sources of neonatal medicine. Neonatology 2008;94:143.

2 Halliday HL, Speer CP: Editorial note. Neonatology 2010;98:I-II.

3 Choi HJ, Hahn S, Lee J, Park BJ, Lee SM, Kim H-S, Bae C-W: Surfactant lavage therapy for meconium aspiration syndrome: a systematic review and meta-analysis. Neonatology 2012;101:183-191.

4 Doyle LW, Ehrenkranz RA, Halliday HL: Dexamethasone treatment after the first week of life for bronchopulmonary dysplasia in preterm infants: a systematic review. Neonatology 2010;98:289-296.

5 Wheeler KI, Klingenberg C, Morley CJ, Davis PG: Volume-targeted versus pressure-limited ventilation for preterm infants: a systematic review and meta-analysis. Neonatology 2011;100:219-227.

-6 Doyle LW, Ehrenkranz RA, Halliday HL: Postnatal hydrocortisone for preventing or treating bronchopulmonary dysplasia in preterm infants: a systematic review. Neonatology 2010;98:111-117.

7 Saugstad OD, Aune D: In search of the optimal oxygen saturation for extremely low birth weight infants: a systematic review and meta-analysis. Neonatology 2011;100:1-8.

-8 Neuman R, Schulzke SM, Buhrer C: Oral ibuprofen versus intravenous ibuprofen or intravenous indomethacin for the treatment of patent ductus arteriosus in preterm infants: a systematic review and meta-analysis. Neonatology 2012;102:9-15.

-9 Soll RF: Cochrane review update: Early erythropoietin for preventing red blood cell transfusion in preterm and/or low birth weight infants. Neonatology 2012;102:127-129.

\begin{tabular}{|c|c|}
\hline KARGER & $\begin{array}{l}\text { () } 2012 \text { S. Karger AG, Basel } \\
1661-7800 / 12 / 1022-0126 \$ 38.00 / 0\end{array}$ \\
\hline $\begin{array}{l}\text { Fax +4161 } 3061234 \\
\text { E-Mail karger@karger.ch } \\
\text { www.karger.com }\end{array}$ & $\begin{array}{l}\text { Accessible online at: } \\
\text { www.karger.com/neo }\end{array}$ \\
\hline
\end{tabular}

